\title{
PEMBERDAYAAN MASYARAKAT MELALUI KOMUNIKASI PEMBANGUNAN BAGI MASYARAKAT NELAYAN DI SEMBALUN LOANG BALOQ GUNA MENJEMBATANI KESENJANGAN SOSIAL MASYARAKAT
}

\author{
Najamudin \\ Dosen Prodi. PBA FTK UIN Mataram
}

\begin{abstract}
Abstrak: Kondisi masyarakat pesisir dan nelayan di lokasi pemberdayaan masih belum terbebas dari persoalan yang dihadapi oleh pelaku usaha kecil menengah meliputi, akses terhadap aset dan sumber-sumber modal terbatas, kebutuhan akan penguatan kelembagaan kelompok untuk pengembangan kapasitas pengelolaan sumber daya pesisir dan laut. Peran penting komunikasi pembangunan dalam pemberdayaan masyarakat pesisir adalah menjembatani kesenjangan yang terjadi antara kondisi masyarakat saat ini dengan kondisi yang ingin dicapai melalui proses-proses komunikasi yang partisipatif, dialogis dan memotivasi.

Strategi komunikasi pembangunan untuk wilayah pesisir hendaknya spesifik lokasi, dengan mempertimbangkan hal-hal seperti program pembangunan perlu menjaga keseimbangan antara pembangunan fisik dan non fisik, tidak hanya mengejar pertumbuhan, tetapi harus menanamkan modal manusia untuk masa depan, pesanpesan dalam komunikasi pembangunan tersebut ditentukan berdasarkan kebutuhan masyarakat nelayan dan ditransformasikan kepada masyarakat melalui metode-metode yang relevan dengan situasi dan kondisi setempat. Diperlukan perencanaan yang matang dalam rancang bangun strategi komunikasi pembangunan, melibatkan peran serta masyarakat pesisir dan stakeholders terkait dalam proses perencanaan, pelaksanaan, evaluasi hingga tindak lanjut dan sinkronisasi dan koordinasi antar stakeholders terkait dengan masyarakat pesisir dapat menjamin keberlanjutan program pembangunan dan mendorong terwujudnya struktur sosio-ekonomi masyarakat lokal yang kuat.
\end{abstract}

Kata Kunci: Pemberdayaan Masyarakat, Komunikasi, Pembangunan.

\section{PENDAHULUAN}

Masyarakat pesisir memiliki kehidupan yang khas, dihadapkan langsung pada kondisi ekosistem yang keras, dan sumber kehidupan yang bergantung pada pemanfaatan sumber daya pesisir dan laut (selanjutnya disingkat SDP). Masyarakat pesisir terutama nelayan kecil, masih terbelit oleh persoalan kemiskinan dan keterbelakangan. Terdapat persoalan tertentu terkait dengan 
Transformasi, Vol. 13, No. 1, Januari 2017: 27 - 43

aspek ekologis, sosial, dan ekonomi, sehingga masyarakat pesisir masih tertinggal. Rendahnya taraf hidup masyarakat pesisir dan akses yang terbatas akan aset dan sumber-sumber pembiayaan bagi nelayan kecil merupakan persoalan utama yang dijumpai di kawasan

Nelayanpun sangat rentan terhadap tekanan pemilik modal. ${ }^{3}$ Kegiatan pembangunan di kawasan pesisir tidak terlepas dari daya dukung lingkungan, keberlangsungan sumber daya alam dan dilakukan secara terpadu oleh berbagai pihak terkait dengan menekankan peningkatan kesejahteraan masyarakat setempat. Ketersediaan sumber daya alam di daratan seperti hutan, bahan tambang, dan mineral serta lahan pertanian produktif semakin menipis sedangkan kebutuhan penduduk terus bertambah sejalan dengan jumlah penduduk Indonesia yang terus meningkat dan diprediksikan akan mencapai 267 juta jiwa pada tahun 2015. ${ }^{4}$ Kebutuhan penduduk tersebut tidak akan mampu dipenuhi seluruhnya oleh sumber daya alam di daratan mengingat luas daratan Indonesia hanya sepertiga dari luas Indonesia keseluruhan, yaitu $1.926 .337 \mathrm{~km}^{2}$. Sektor perikanan dan kelautan sangat potensial untuk dikembangkan, mengingat Indonesia merupakan negara kepulauan terbesar di dunia yang memiliki 17.506 buah pulau, dengan garis pantai sepanjang $81.000 \mathrm{~km}$, dan luas laut sekitar 3,1 juta km². Selain itu, Indonesia juga memiliki hak pengelolaan sumber daya alam hayati dan nonhayati di perairan Zona Ekonomi Eksklusif Indonesia (ZEEI), yaitu perairan yang berada 12 hingga 200 mil dari garis pantai titik-titik terluar kepulauan Indonesia, yang luasnya 2.7 juta $\mathrm{km}^{2}$ berdasarkan United Convention on the Law of the Seas. ${ }^{5}$

Kegiatan sektor perikanan dan kelautan, memiliki dua bidang usaha yaitu perikanan darat dan perikanan tangkap. Hasil penelitian tentang pendekatan penyuluhan pada masyarakat pesisir memperlihatkan bahwa setiap komunitas memiliki keunikan dan berbeda dalam hal nilai, orientasi, dan kebutuhan

${ }^{3}$ R. Dahuri. Pendayagunaan Sumber Daya Kelautan Untuk Kesejahteraan Rakyat (Kumpulan Pemikiran DR. Ir. Rokhmin Dahuri, MS). Jakarta: LISPI (Lembaga Informasi dan Studi Pembangunan Indonesia) bekerjasama dengan DIrektorat Jenderal Pesisir, Pantai dan Pulau-Pulau Kecil, Dep. Eksplorasi Laut dan Perikanan. 2000

${ }^{4}$ Siti Amanah, dkk. Pemodelan Penyuluhan Perikanan Pada Masyarakat Pesisir Secara Partisipatif. Laporan Penelitian Hibah Bersaing X. IPB, Bogor. 2004.

5 Achludin Rochim, Komunikasi Sosial Pembangunan. Surabaya: LP21. 2010), h. 53 
pengembangan diri, kelompok, komunitas, serta daya dukung lingkungan fisik. Dalam hal ini komunikasi pembangunan dapat menjadi wahana transformasi situasi masyarakat dari sekarang ke kondisi yang lebih baik. ${ }^{6}$

Dari beberapa gambaran kehidupan masyarakat nelayan secara umum tersebut, maka ada ketertarikan untuk mengkaji permasalahan pemberdayaan masyarakat dengan "Pemberdayaan Masyarakat Melalui Komunikasi Pembangunan Bagi Masyarakat Nelayan Di Sembalun Loang Baloq Guna Menjembatani Kesenjangan Sosial Masyarakat"

\section{PEMBAHASAN}

\section{A. Pemberdayaan Masyarakat Melalui Komunikasi Pembangunan Guna Menjembatani Kesenjangan Sosial Masyarakat Bagi Masyarakat Nelayan Di Sembalun Loang Baloq.}

Pertama Observasi Awal Yang Dilakukan Pada Tanggal 16-17 Juli 2017. Salahsatu tujuan dari program pengabdian kepada masyarakat yang diselenggarakan oleh LP2M UIN Mataram adalah untuk menggali potensi masyarakat dan memanfaatkannya sebagai solusi atas permasalahan yang mereka hadapi. Oleh karena itu agar tujuan LP2M / pengabdian tersebut tepat sasaran, maka dilakuakanlah observasi awal agar memiliki gambaran yang konprehensip tentang masyarakat yang menjadi obyek yang diberdayakan. ${ }^{7}$ Pada tahap awal observasi ditemukan fakta-fakta tentang masyarakat, terutama tentang gambaran pengelolaan pesisir di wilayah Loang Baloq.

Gambaran permasalahan tersebut oleh pengabdi dibagi ke dalam tiga wilayah pengembangan yaitu, lokasi sebelah utara dijadikan sebagai lokasi wisata (Taman Loang Baloq), lokasi tengah dijadikan sebagai tempat penangkapan ikan dan lokasi sebelah selatan dijadikan sebagai lokasi wisata (Pantai Gading). Guna mengantisipasi hal tersebut, strategi komunikasi pembangunan perikanan dan kelautan harus berfokus pada peningkatan

\footnotetext{
${ }^{6}$ Siti Amanah. Kearifan Lokal dalam Pengembangan Komunitas Pesisir. (Bandung: CV. Citra Praya. 2007), h. 32

${ }^{7}$ Pedoman Pelaksanaan Kegiatan Dalam Penelitian dan Pengabdian Masyarakat (P2M) Institut Agama Islam Negeri (IAIN) Mataram Tahun 2016
} 
Transformasi, Vol. 13, No. 1, Januari 2017: 27 - 43

kemampuan nelayan dalam pengelolaan teknologi penangkapan, penguatan kapasitas permodalan, kemampuan pengelolaan keuangan dan yang paling urgen adalah perubahan sikap dan perilaku yang positif memanfaatkan kekayaan bahari.

Kegiatan nelayan di Loang Balok selain kegiatan pariwisata, adalah melakukan penangkapan ikan. Beberapa dusun melakukan kegiatan memandu wisatawan menikmati pemandangan laut dan mengamati panorama alam yang ada, dan perempuan nelayan menjual ikan hasil tangkapan. Kegiatan nelayan adaah menjual ikan bakar, berjualan di lokasi wisata dan pengolahan ikan oleh wanita nelayan. Aktivitas penangkapan ikan di dua lokasi kajian sangat dipengaruhi oleh musim, yaitu pada musim panen ikan, nelayan umumnya berangkat pada dini hari dan pulang lebih cepat (sekitar pukul 2.00 atau 3.00 dini hari melaut dan kembali pukul 7.00 hingga pukul 8.00 ). Pada saat populasi ikan rendah, nelayan di dua dusun melakukan kegiatan tani dan mengandalkan hasil ikan di alat tangkap bagan dan berangkat pukul 18.00 petang dan baru kembali keesokan hari pada pukul 06.00 pagi hari. Nelayan membutuhkan pendampingan dalam hal pemasaran hasil, pemeliharaan terumbu karang, kawasan pesisir dan penguatan kelembagaan kelompok nelayan. Proses-proses komunikasi pembangunan yang saat ini berlangsung masih terlalu berfokus pada sosialisasi informasi tentang program kerja dan prioritas pemerintah, belum mengarah pada terobosan pendayagunaan saluran dan media komunikasi lokal untuk memperkuat jaringan sosial masyarakat pesisir.

Kurangnya kesadaran, kreatifitas, keterbatasan peluang. lapangan kerja, usaha, dukungan pemerintah dalam pengelolaan potensi sumberdaya khusnya kelautan dan mengelola hasil tangkapan ikan dan lain sebagainya menjadi sebuah permasalahan tersendiri yang dihadapi oleh masyarakat Dusun Sembalun Loang Baloq, terutama bagi masyarakat yang menggantungan kehidupan ekonomi keluarga mereka melalui hasil penangkapan ikan, sehingga permasalahan tersebut perlu mendapatkan penangan tersendiri guna menemukan solusi atas permasalahan masyarakat tersebut. Beberapa 
gambaran permasalahan dan potensi sumberdaya alam dan manusia yang ada di Dusun Sembalun Loang Baloq tersebut menjadi data temuan pada observasi awal, sehingga dalam pandangan pengabdi sendiri perlu difasilitasi oleh LP2M untuk diberdayakan. ${ }^{8}$

\section{B. Pemetaan Potensi Masyarakat Sebagai Solusi Dalam Pemberdayaan Masyarakat Melalui Komunikasi Pembangunan Guna Menjembatani Kesenjangan Sosial Masyarakat Bagi Masyarakat Nelayan Di Sembalun Loang Baloq.}

Pengelolaan pesisir di wilayah Dusun Sembalun Loang Baloq dibagai menjadi tiga wilayah sebagaimana yang telah dijelaskan sebelumnya, yaitu lokasi sebelah utara dijadikan sebagai lokasi wisata (Taman Loang Baloq), lokasi tengah dijadikan sebagai tempat penangkapan ikan dan lokasi sebelah selatan dijadikan sebagai lokasi wisata (Pantai Gading). Guna mengantisipasi hal tersebut, strategi komunikasi pembangunan perikanan dan kelautan harus berfokus pada peningkatan kemampuan nelayan dalam pengelolaan teknologi penangkapan, penguatan kapasitas permodalan, kemampuan pengelolaan keuangan dan yang paling urgen adalah perubahan sikap dan perilaku yang positif memanfaatkan kekayaan bahari.

Kegiatan nelayan di Loang Balok selain kegiatan pariwisata, adalah melakukan penangkapan ikan. Beberapa dusun melakukan kegiatan memandu wisatawan menikmati pemandangan laut dan mengamati panorama alam yang ada, dan perempuan nelayan menjual ikan hasil tangkapan. Kegiatan nelayan adaah menjual ikan bakar, berjualan di lokasi wisata dan pengolahan ikan oleh wanita nelayan. Aktivitas penangkapan ikan di dua lokasi kajian sangat dipengaruhi oleh musim, yaitu pada musim panen ikan, nelayan umumnya berangkat pada dini hari dan pulang lebih cepat (sekitar pukul 2.00 atau 3.00 dini hari melaut dan kembali pukul 7.00 hingga pukul 8.00 ). Pada saat populasi ikan rendah, nelayan di dua dusun melakukan kegiatan tani dan

Selo Sumarjan, Masyarakat dan Manusia Dalam Pembangunan, Pokok-Pokok Pikiran Selo Sumarjan, (Jakarta: Sinar Harapan,1993), h. 2-4 
Transformasi, Vol. 13, No. 1, Januari 2017: 27 - 43

mengandalkan hasil ikan di alat tangkap bagan dan berangkat pukul 18.00 petang dan baru kembali keesokan hari pada pukul 06.00 pagi hari.

Gambaran mengenai kondisi nelayan tersebut secara tidak langsung perlu mendapatkan perhatian dari berbagai pihak untuk segera melaksanakan pendampingan, pemberdayaan, pembangunan dalam hal pemasaran hasil, pemeliharaan terumbu karang, kawasan pesisir dan penguatan kelembagaan kelompok nelayan agar kesenjangan yang ada di tengah masyarakat Dusun Sembalun, Loang Baloq dan Pantai Gading bisa diminimalisir dan bahkan bisa dihilangkan. Sementara realitas tentang proses-proses komunikasi pembangunan yang saat ini berlangsung masih terlalu berfokus pada sosialisasi informasi tentang program kerja dan prioritas pemerintah, belum mengarah pada terobosan pendayagunaan saluran dan media komunikasi lokal untuk memperkuat jaringan sosial masyarakat pesisir.

Oleh karena itu guna mengantisipasi hal tersebut, strategi komunikasi pembangunan perikanan dan kelautan harus berfokus pada peningkatan kemampuan nelayan dalam pengelolaan teknologi penangkapan, penguatan kapasitas permodalan, kemampuan pengelolaan keuangan dan yang paling urgen adalah perubahan sikap dan perilaku yang positif memanfaatkan kekayaan bahari.

Kegiatan nelayan di Dusun Sembalun adalah melakukan penangkapan ikan. Beberapa dusun lainnya seperti Loang Baloq dan PAntai Gading melakukan kegiatan di bidang pariwisata, menikmati pemandangan laut dan berdagang ikan disekitar pantai di pagi hari hingga malam hari yang rata-rata dilakukan oleh perempuan nelayan.

Kegiatan nelayan di Dusun Sembalun meliputi menangkap ikan dan pengolahan ikan oleh wanita nelayan. Aktivitas penangkapan ikan di pantai sekitar Sembalun sangat dipengaruhi oleh musim, yaitu pada musim panen ikan, nelayan umumnya berangkat pada dini hari dan pulang lebih cepat (sekitar pukul 2.00 atau 3.00 dini hari melaut dan kembali pukul 7.00 hingga pukul 8.00). Pada saat populasi ikan rendah, nelayan di dua desa melakukan kegiatan tani dan mengandalkan hasil ikan di alat tangkap bagan dan 
berangkat pukul 18.00 petang dan baru kembali keesokan hari pada pukul 06.00 pagi hari. Nelayan membutuhkan pendampingan dalam hal pemasaran hasil, pemeliharaan terumbu karang, kawasan pesisir dan penguatan kelembagaan kelompok nelayan. Proses-proses komunikasi pembangunan yang saat ini berlangsung masih terlalu berfokus pada sosialisasi informasi tentang program kerja dan prioritas pemerintah, belum mengarah pada terobosan pendayagunaan saluran dan media komunikasi lokal untuk memperkuat jaringan sosial masyarakat pesisir.

\section{Strategi Komunikasi Pembangunan dalam Menjembatani Kesenjangan Masyarakat Loang Baloq, Sembalun dan Pantai Gading}

Menghadapi permasalahan masyarakat pesisir di lokasi kajian, maka dalam aplikasinya di lapangan dapat dikomunikasikan program berikut:

1. Peningkatan keterampilan nelayan dan keluarganya dalam mengelola hasil tangkapan, memperbaiki sikap yang merusak lingkungan dengan mensosialisasikan pentingnya menjaga kelestarian sumber daya alam;

2. Peningkatan kemampuan manajemen usaha penangkapan dan diversifikasi usaha yang disertai penguatan ekonomi keluarga melalui usaha produktif;

3. Penguatan kelembagaan lokal termasuk organisasi pemasaran hasil perikanan;

4. Pengelolaan wilayah pesisir secara terpadu dengan mengedepankan prinsip sustainability (sumber daya alam) dan kesejahteraan masyarakat; dan

5. Membangun jejaring (network) dengan mitra usaha guna memperbesar armada dan menggunakan alat tangkap yang lebih efektif dan tidak merusak lingkungan.

Dengan demikian, pesan-pesan atau materi dalam komunikasi pembangunan masyarakat pesisir tidak sekedar mentransferkan informasi saja, tetapi menyangkut aspek transformasi keadaan dari kondisi sekarang yakni nelayan dan keluarganya yang masih terpinggirkan, menjadi lebih mandiri, sejahtera dan bermartabat. Komunikasi pembangunan dapat 
Transformasi, Vol. 13, No. 1, Januari 2017: 27 - 43

memainkan peran dalam perubahan berencana, sebagaimana dikemukakan pula oleh S.C. Dube (Shramm \& Lerner 1976), bahwa dalam pembangunan di India, komunikasi memegang peran nyata dalam mengembangkan media untuk memobilisasi masyarakat dan pemerintahnya.

Fenomena tersebut sebagaimana dengan yang terjadi pada salah satu dusun yakni Dusun Loang Baloq, dimana terdapat kerjasama antara nelayan dengan pemerintah setempat dan kelompok karang taruna dalam pengelolaan potensi dan kelestarian sumber daya laut. Sebetulnya masyarakat Dusun Sembalun telah memiliki peraturan "awig-awig" / aturan adat yang menyebutkan bahwa setiap perusak lingkungan akan dikenakan sanksi, yakni pembinaan awal, yang apabila dilanggar sampai tiga kali maka ada sanksi khusus. Akan tetapi, kesadaran bahwa laut harus dipelihara kelestariannya sudah mulai tumbuh di kalangan masyarakat.

Komentar nelayan itu memperlihatkan bahwa nelayan sesungguhnya memiliki kepedulian atas degradasi lingkungan yang dipicu oleh kebutuhan ekonomis. Nelayan mengeluhkan minimnya penegakan hukum dan modal yang terbatas untuk berusaha di bidang lain. Atas latar belakang inilah maka secara bertahap diadakan pendekatan melalui pertemuan dengan tokoh-tokoh pemerintah, adat, agama, pemuda dan nelayan untuk menimbulkan kesadaran pemahaman pentingnya pemeliharaan laut, khususnya kawasan wisata. Usaha ini mulai menampakkan hasil yang menggembirakan. Beberapa tahun kemudian, kegiatan penangkapan ikan dengan bom dan potasium sudah berkurang dan penghasilan nelayan pun bertambah. Hal ini didukung oleh kerjasama antara masyarakat setempat dengan pemerintah dan nelayan dalam pelarangan penangkapan ikan dengan menggunakan alatalat yang merusak potensi sumberdaya laut.

Sejatinya, dalam kaitan pengelolaan sumber daya perikanan berbasis masyarakat (PSPBM), Nikijuluw (2002) menyebutkan bahwa di beberapa daerah di Indonesia seperti Maluku, dalam menangkap ikan hanya menggunakan alat tangkap sederhana. Sedangkan di Irian Jaya menurut Nikijuluw (2002) menerapkan aturan bahwa jika penduduk suatu suku ingin 
menangkap ikan di perairan yang menjadi wilayah suku lain, maka teknologi yang digunakan harus sama. Kehadiran alat tangkap modern, cenderung mendesak nelayan kecil untuk meninggalkan daerahnya dan keluar dari perairan daerah asalnya, sehingga seringkali menimbulkan konflik antara nelayan satu dengan lain karena perebutan fishing ground dan penggunaan teknologi yang berbeda. Atas dasar pemikiran ini, maka sebenarnya peran program komunikasi pembangunan sangat luas mulai dari sekedar pentransferan informasi dan teknologi, pemberdayaan hingga peningkatan pemahaman masyarakat akan nilai-nilai budaya lain (able to understand). ${ }^{9}$

Beberapa jawaban dari pertanyaan yang dilontarkan kepada perempuan nelayan di Dusun Sembalun pada saat pelaksanaan kegiatan pemberdayaan menunjukkan bahwa kelompok perempuan masih berkutat pada persoalan domestik, belum ada inovasi yang sesuai dengan nilai-nilai lokal yang dapat mengefisienkan waktu untuk kegiatan domestik. Jika dapat diefisienkan, maka kaum perempuan ada kesempatan untuk mengembangkan diri dan keluarganya dalam kegiatan sosial ekonomi untuk peningkatan kualitas hidup keluarga. Pengolahan hasil perikanan tangkap untuk fish nugget belum menjadi minat nelayan setempat.

Terdapat tiga hal yang menyebabkan perempuan nelayan tidak ada peluang untuk mengelola usaha pengolahan ikan dengan menggunakan metode yang lebih menjanjikan dan member keuntungan bagi mereka, yaitu (i) kebutuhan uang (cash) yang mendesak; (ii) keterbatasan waktu dan modal usaha; dan (iii) pemasaran. Dengan demikian, orientasi komunikasi pembangunan di kawasan pesisir cukup berat karena bukan hanya dituntut mampu mengubah pengetahuan, tetapi juga mengubah sikap dan membantu memperkuat struktur sosial ekonomi nelayan, sehingga lebih kuat dalam menghadapi tantangan.

${ }^{9}$ Siti Amanah, dkk.. Pemodelan Penyuluhan Perikanan Pada Masyarakat Pesisir Secara Partisipatif. (Laporan Penelitian Hibah Bersaing X. IPB, Bogor. 2004) 
Transformasi, Vol. 13, No. 1, Januari 2017: 27 - 43

\section{Strategi Komunikasi Pembangunan pada Masyarakat Pesisir Loang Baloq, Sembalun dan Pantai Gading.}

Pelaksanaan program pemberdayaan yang selama ini dilakukan oleh pemerintah maupun oleh lembaga-lembaga non pemerintah lainnya masih belum berorientasi pada pengutamaan kebutuhan masyarakat. Pada tahun 2000 secara lebih intensif diterapkan pendekatan yang mengutamakan penyelesaian persoalan masyarakat (problem solving) dan berpusat pada kebutuhan masyarakat (people centered development). Contoh kasus: pendekatan berpusat pada nelayan diterapkan pada program rehabilitasi karang sebagai salah satu pilihan atas solusi persoalan degradasi lingkungan. ${ }^{10}$

Gambaran permasalahan tersebut secara tidak langsung menegaskan bahwa terdapat befbagai macam persoalan dalam pemberdayaan masyarakat yang dilakukan oleh pemerintah maupun oleh lembaga-lembaga non pemerintah. Oleh karena itu, dalam hal ini sudah seharusnya dapat mengambil sebuah pembelajaran dari beberapa kasus-kasus pemberdayaan yang pernah dilakukan. Oleh karena itu diperlukan Komunikasi pembangunan harus diselenggarakan secara partisipatif, sebab pendekatan ini memudahkan agent of change membantu masyarakat menyelesaikan persoalannya. Komunikasi pembangunan dapat dipandang sebagai upaya pemberdayaan masyarakat, yang dalam kegiatannya berkaitan dengan orang dewasa. Implikasi hal ini, pendekatan yang digunakan adalah pembelajaran orang dewasa (adult learning approach) dalam penyiapan dan penyelenggaraan perlu dipusatkan dalam kebutuhan nyata peserta proses belajar (Amanah 1996) atau lebih dikenal dengan learner-centred approaches. Orang dewasa merupakan orang yang sudah kaya pengalaman sebagaimana dikemukakan oleh (Simpson 1993) sehingga perlu memperhatikan hal-hal berikut:

1. Pembelajaran orang dewasa didasarkan pada pengalaman masa lalu dan patut dihargai.

${ }^{10}$. Ibid., h. 12 
2. Pengalaman masa lampau tersebut harus dihargai oleh peserta lainnya dan harus diupayakan diterapkan dalam proses belajar. Pembelajaran yang melibatkan transformasi pengalaman masa lalu membutuhkan waktu dan tenaga yang lebih besar dibandingkan model belajar lainnya.

3. Lingkungan mempengaruhi kemampuan orang dewasa dalam belajar. Lingkungan terbaik seperti kondisi yang mengurangi gangguan pada orang dewasa yang sedang belajar akan memberikan dukungan yang berharga. Peserta dewasa akan belajar dengan baik di lokasinya sendiri. Orang dewasa tidak akan efektif jika belajar di bawah tekanan atau waktu yang dibatasi. Mereka tidak suka membuang waktu, dan orang dewasa lebih tertarik padaa proses belajar yang memberikan hasil nyata yang nyata dan cepat.

4. Orang dewasa akan belajar bahan atau materi yang dia perlukan (selektif).

5. Orang dewasa dapat didorong untuk belajar pada materi yang relevan pada peran dan kehidupannya saat ini.

6. Orang dewasa belajar untuk kehidupannya dan untuk mereka yang terlibat dalam kelompoknya.

Prinsip partisipasi dalam komunikasi pembangunan bukan sebatas proses sekedar hadir, memberikan pendapat atau hanya berdasarkan persepsi pemerintah atau penyuluh sendiri. Sangat rasional, jika masyarakat pesisir belum mau terlibat dalam berbagai program pembangunan khususnya kegiatan penyuluhan karena sejak awal masyarakat tidak terlibat dalam menentukan kegiatan yang diprogramkan. Terkait dengan hal ini, proses aksi sosial dan proses pengambilan keputusan dalam model adopsi inovasi Rogers (1994) dapat dimodifikasi. Proses aksi sosial meliputi lima tahap: (1) stimulasi minat (stimulation of interest) yaitu inisiatif dalam komunitas mulai berkembang pada tahap awal dalam ide baru dan praktek; (2) inisiasi (initiation) yaitu kelompok yang besar mempertimbangkan ide baru atau praktek dan alternatif dalam implementasi; (3) legitimitasi (/egitimation) merupakan tahap saat pimpinan komunitas memutuskan akan meneruskan 
Transformasi, Vol. 13, No. 1, Januari 2017: 27 - 43

tindakan atau tidak; (4) keputusan bertindak adalah rencana spesifik tindakan mulai dibangun; dan (5) aksi yaitu penerapan rencana.

Model adopsi inovasi Rogers meliputi lima tahap: (1) pengetahuan (knowledge) seseorang menjadi sadar akan adanya ide atau cara baru; (2) persuasi (persuasion) yaitu individu mulai mengembangkan sikap suka atau tidak suka terhadap ide tersebut, (3) keputusan (decision) adalah individu membuat keputusan awal untuk mengadopsi atau tidak ide tersebut; (4) implementasi (implementation) adalah individu mencoba ide atau cara baru tersebut untuk pertama kali; dan (5) konfirmasi (confirmation) adalah individu memutuskan menerapkan ide atau cara baru secara berulang dan dapat disertai modifikasi.

Menumbuhkembangkan partisipasi masyarakat dalam pembangunan wilayah pesisir tidak cukup hanya dengan mengidentifikasi isu yang dihadapi saja, tetapi perlu diwujudkannya beberapa aspek yaitu adanya aspek situasional, kolaborasi dan evaluasi diri dari setiap unsur yang terkait dengan perencanaan, pelaksanaan dan evaluasi program. Agent of change seyogyanya mampu mengembangkan empat aspek (Kemmis \& McTaggart 1988), yaitu:

1. Suatu kondisi yang memungkinkan tumbuhnya kebersamaan dalam kelompok masyarakat dan rasa memiliki problem yang tengah dihadapi;

2. Adanya kemampuan berkreasi dan pemikiran yang kritis;

3. Program yang dilaksanakan adalah untuk tujuan perbaikan dan pengembangan; dan

4. Kemampuan memfasilitasi masyarakat untuk membantu menyelesaikan masalah.

Pihak terkait dengan program komunikasi pembangunan perlu mengetahui tipe partisipasi masyarakatnya, sehingga dapat mengembangkan pendekatan yang dapat mempertahankan dan meningkatkan partisipasi masyarakat di wilayahnya. Idealnya, masyarakat memiliki tipologi keenam dan ketujuh. Meskipun demikian, jika masyarakat sudah berada pada tipologi kelima itu sudah bagus karena sudah ada langkah maju untuk berinisiatif 
membentuk dan mengembangkan organisasi di lingkungan mereka sendiri. Hal ini dapat dibanding dengan hasil penelitian Douglah dan Sicilima di Tanzania (1997) tentang pelibatan masyarakat dalam dua pendekatan penyuluhan yaitu Latihan dan Kunjungan dan Sasakawa Global 2000. Partisipasi pada kedua pendekatan belum menerapkan pendekatan partisipasi yang berimbang. Partisipasi masih ditekankan hanya pada pelaksanaan ketimbang pelibatan petani saat perencanaan dan evaluasi program. Tampak bahwa prinsip partisipasi bukanlah hal yang mudah untuk diterapkan. Penerapan metode partisipasi memerlukan proses yang bertahap. Penumbuhan partisipasi perlu dimulai dengan fasilitasi pada masyarakat pesisir tentang pentingnya keterlibatan yang bersangkutan pada kegiatan yang bermanfaat bagi masyarakat sekaligus untuk memperbaiki hidup dan kehidupan. Pada tahap awal bentuk partisipasi bisa berupa pemanfaatan hasilhasil penyuluhan (inovasi), lalu partisipasi akan lebih intensif secara bertahap, hingga akhirnya masyarakat mampu mandiri untuk mengelola kegiatannya dengan mobilisasi diri.

\section{E. Strategi Pelibatan Stakeholders yang dalam Komunikasi} Pembangunan Masyarakat Pesisir Di Wilayah Loang Baloq, Sembalun dan Pantai Gading.

Masyarakat pesisir merupakan sistem sosial, sehingga framework CATWOE ini relevan dengan proses transformasi masyarakat pesisir ke arah yang lebih baik. Dengan demikian, pihak terkait yang dapat komunikasi pembangunan berorientasi pemberdayaan meliputi:

1. Customers. Masyarakat pesisir termasuk nelayan dan anggota keluarganya,

2. Actors. Pemuka masyarakat, agen pembaharu, penyuluh, ketua dan anggota kelompok nelayan,

3. Transformation: proses perubahan berupa proses komunikasi pembangunan yang ditujukan untuk meningkatkan martabat masyarakat pesisir, seperti kegiatan penguatan kelembagaan lokal (seperti lembaga pemasaran, kelompok nelayan), pengembangan kapasitas sumber daya 
Transformasi, Vol. 13, No. 1, Januari 2017: 27 - 43

manusia setempat, pengelolaan sumber daya pesisir dan lautan terpadu dan lain-lain.

4. Welstanchaung $=$ worldview: pemahaman terhadap cara pandang, nilainilai lokal yang dianut oleh masyarakat pesisir, dan dihargai sebagai aset masyarakat setempat. Di wilayah pengabdian/pemberdayaan dan penelitian, masing-masing kelompok nelayan memiliki awig-awig (peraturan yang dikelola oleh komunitas lokal dan didasarkan pada adat istiadat dan budaya masyarakat setempat) sangat ditaati oleh nelayan dan masyarakat pesisir setempat.

5. Owners. Dinas Kelautan dan Perikanan, Dinas Pariwisata, Dinas Perdagangan dan Perindustrian, pemerintahan desa dan kecamatan dan instansi terkait lainnya yang berfungsi mengembangkan masyarakat setempat

6. Environment: Kondisi lingkungan setempat perlu diperhatikan seperti kebijakan lokal apakah mendukung atau tidak terhadap program pemberdayaan masyarakat pesisir.

Sebagai sebuah sistem sosial, masyarakat pesisir tentunya memiliki struktur sosial tertentu, dan dikenalnya status dan peran pada tiap anggota masyarakat. Strategi komunikasi pembangunan pada masyarakat bersifat spesifik untuk tiap wilayah, setiap upaya perubahan perlu mempertimbangkan berbagai faktor seperti masalah sosial ekonomi, kondisi fisik lingkungan (sumber daya alam), dan sumber daya manusia secara umum (termasuk agen pembaharu).

Unsur-unsur yang terlibat dalam komunikasi pembangunan berubahubah dan harus diantisipasi secepatnya. Perubahan merupakan proses alamiah yang tidak bisa dihindari dan harus terjadi pada sesuatu, individu atau masyarakat sebagai reaksi atau adaptasi pada kondisi yang dihadapi. Proses perubahan pada masyarakat pesisir dalam konteks perubahan sosial ke arah yang lebih baik berkaitan dengan transformasi struktur dan interaksi sosial dari sebuah masyarakat dan merupakan variasi atau modifikasi dalam pola organisasi sosial atau subkelompok dalam masyarakat atau pada keseluruhan 
masyarakat itu sendiri. Dengan demikian, kendala-kendala yang dihadapi dan masalah yang timbul diantaranya adalah adanya keinginan untuk mempertahankan status quo oleh sekelompok masyarakat yang dapat mempengaruhi proses perubahan. Sebagai mana diketahui, dalam teori adopsi-inovasi ada tahapan yang dilalui jika suatu ide baru diterapkan dan proses itu merupakan proses mental. Setiap tahap akan memerlukan waktu, pemikiran dan respon yang berlainan (awareness, interest, trial, evaluation dan keputusan apakah menolak ataukah menerima inovasi (pembaharuan ide atau teknologi baru). Guna mengantisipasi hal ini, maka sangat relevan bagi agen pembaharu untuk menerapkan pendekatan penyuluhan yang tepat sesuai dengan tahapan komunikasi yang sedang berlangsung di masyarakat.

Terdapat tiga pilihan metode pendekatan atau kombinasi ketiganya yang dapat digunakan dalam pelaksanaan program ketahanan pangan, yaitu:

a. Pendekatan perorangan, misalnya kegiatan kunjungan perorangan, konsultasi ke rumah, penggunaan surat atau telpon, dan magang.

b. Pendekatan kelompok, misalnya kursus tani-nelayan, demonstrasi cara atau hasil, kunjungan kelompok, karyawisata, diskusi kelompok, ceramah, pertunjukan film, slide, karyawisata, penyebaran brosur, buletin, folder, liptan, asah terampil, sarasehan, rembug utama atau madya, temu wicara, temu usaha, temu karya dan temu lapang.

c. Pendekatan massal seperti pameran, Pekan Nasional (Penas), Pekan Daerah (Peda), pertunjukan film atau wayang, drama, penyebaran pesan melalui siaran radio, televisi, surat kabar, selebaran atau majalah, pemasangan poster atau spanduk dan sebagainya. ${ }^{11}$

\section{KESIMPULAN}

Kondisi masyarakat pesisir dan nelayan di lokasi pemberdayaan belum terbebas dari persoalan yang dihadapi oleh pelaku usaha kecil menengah meliputi, akses terhadap aset dan sumber-sumber modal terbatas, kebutuhan akan penguatan kelembagaan kelompok untuk pengembangan kapasitas pengelolaan

\footnotetext{
${ }^{11}$ Siti Amanah, Op.cit., hlm, 46
} 
Transformasi, Vol. 13, No. 1, Januari 2017: 27 - 43

sumber daya pesisir dan laut. Peran penting komunikasi pembangunan dalam pemberdayaan masyarakat pesisir adalah menjembatani kesenjangan yang terjadi antara kondisi masyarakat saat ini dengan kondisi yang ingin dicapai melalui proses-proses komunikasi yang partisipatif, dialogis dan memotivasi.

Strategi komunikasi pembangunan untuk wilayah pesisir hendaknya spesifik lokasi, dengan mempertimbangkan hal-hal berikut:

1. Program pembangunan perlu menjaga keseimbangan antara pembangunan fisik dan non fisik, tidak hanya mengejar pertumbuhan, tetapi harus menanamkan modal manusia untuk masa depan;

2. Pesan-pesan dalam komunikasi pembangunan tersebut ditentukan berdasarkan kebutuhan masyarakat nelayan dan ditransformasikan kepada masyarakat melalui metode-metode yang relevan dengan situasi dan kondisi setempat,

3. Diperlukan perencanaan yang matang dalam rancang bangun strategi komunikasi pembangunan, melibatkan peran serta masyarakat pesisir dan stakeholders terkait dalam proses perencanaan, pelaksanaan, evaluasi hingga tindak lanjut dan

4. Sinkronisasi dan koordinasi antar stakeholders terkait dengan masyarakat pesisir dapat menjamin keberlanjutan program pembangunan dan mendorong terwujudnya struktur sosio-ekonomi masyarakat lokal yang kuat.

\section{DAFTAR PUSTAKA}

Achludin Rochim, Komunikasi Sosial Pembangunan. Surabaya: LP21. 2010.

Dewa Waskita. Komunikasi Pembangunan untuk Pemberdayaan. Jurnal Organisasi dan manajemen. Vol 1. No. 1, September 2005.

H. Rochajat Harun,. Komunikasi Pembangunan dan Perubahan Sosial. Jakarta: Grafindo. 2008

Ngainun Naim. Dasar-Dasar Komunikasi Pendidikan. Jakarta: Ar-Ruzz Media. 2011

Hapsara Habib Rachmat, Pembangunan Kesehatan di Indonesia: Prinsip Dasar, Kebijakan, Perencanaan dan Kajian Masa Depannya. Yogyakarta: Gadjah Mada University Press. 2010 
Najamudin, Pemberdayaan Masyarakat Melalui...

Hanafi Hartanto. Keluarga Berencana Dan Kontrasepsi (KB). Jakarta: Pustaka Sinar Harapan. 2010

Ari Sulistyawati, Pelayanan Keluarga Berencana (KB). Jakarta: Salemba Medika. 2011

Pedoman Pelaksanaan Kegiatan Dalam Penelitian dan Pengabdian Masyarakat (P2M) Institut Agama Islam Negeri (IAIN) Mataram Tahun 2016

R. Dahuri. Pendayagunaan Sumber Daya Kelautan Untuk Kesejahteraan Rakyat (Kumpulan Pemikiran DR. Ir. Rokhmin Dahuri, MS). Jakarta: LISPI (Lembaga Informasi dan Studi Pembangunan Indonesia) bekerjasama dengan DIrektorat Jenderal Pesisir, Pantai dan Pulau-Pulau Kecil, Dep. Eksplorasi Laut dan Perikanan. 2000

Selo Sumarjan, Masyarakat dan Manusia Dalam Pembangunan, Pokok-Pokok Pikiran Selo Sumarjan. Jakarta: Sinar Harapan,1993

Sudarwan Danim, Media Komunikasi Pendidikan. Jakarta: Bumi Aksara. 2010

Siti Amanah. Dkk Profil Penyelenggaraan Penyuluhan Perikanan Menunjang Kinerja DKP di Era Globalisasi. Jakarta: STP (dulu AUP). 2002

Siti Amanah. Kearifan Lokal dalam Pengembangan Komunitas Pesisir. Bandung: CV. Citra Praya. 2007

Siti Amanah, dkk. Pemodelan Penyuluhan Perikanan Pada Masyarakat Pesisir Secara Partisipatif. Laporan Penelitian Hibah Bersaing X. IPB, Bogor. 2004.

Siti Amanah. Kearifan Lokal dalam Pengembangan Komunitas Pesisir. Bandung: CV. Citra Praya. 2007

Zulkarimen Nasution, Komunikasi Pembangunan; Pengenalan Teori dan Penerapannya. Jakarta: Pustaka Hidayah. 2011. 